\title{
Geoelectrical Investigation of Groundwater Potential, at Bosso Campus, Minna, Niger State, Nigeria
}

\author{
Aisha Alkali, Jamilu Shehu, Usman Defyan Alhassan, Kazeem Adeyinka Salako, \\ Abdulwaheed Adewuyi Rafiu, Abbas Adebayo Adetona, Usman Usman Hussaini
}

Department of Geophysics, Federal University of Technology, Minna, Nigeria

\section{Email address:}

jameelshehu@futminna.edu.ng (J. Shehu)

\section{To cite this article:}

Aisha Alkali, Jamilu Shehu, Usman Defyan Alhassan, Kazeem Adeyinka Salako, Abdulwaheed Adewuyi Rafiu, Abbas Adebayo Adetona, Usman Usman Hussaini. Geoelectrical Investigation of Groundwater Potential, at Bosso Campus, Minna, Niger State, Nigeria. Journal of Water Resources and Ocean Science. Vol. 8, No. 3, 2019, pp. 37-43. doi: 10.11648/j.wros.20190803.12

Received: June 18, 2019; Accepted: July 10, 2019; Published: October 12, 2019

\begin{abstract}
Geoelectrical investigation of groundwater potential has been carried out at Bosso Staff Quarters Bosso campus, Federal university of Technology, Minna. The area is situated on latitude $9^{0} 38^{\prime} 55.8^{\prime \prime} \mathrm{N}$ and $9^{0} 39^{\prime} 29.0^{\prime \prime} \mathrm{N}$ and longitude $6^{0} 31^{\prime} 19.7^{\prime \prime} \mathrm{E}$ and $6^{0} 31^{\prime} 46.7^{\prime \prime} \mathrm{E}$. the survey was carried out with the aim of delineating the potential area for groundwater development and depth to the groundwater within the study area. The Schlumbeger array was used to sound six profiles with a total of 36 Vertical Electrical Sounding (VES) points. The sounding interpretation results were used to generate geoelectric section. The corresponding geologic section were also generated which revealed the existence of three subsurface layers. These layers revealed the existence of three subsurface layers. These layers comprise the top soil, weathered/fractured basement and fresh basement. The results of this analysis are presented as curves of apparent resistivity versus depth, from the digitalized curves obtained from the IP2WIN software, sulfur 11 was used to generates iso-resistivity map at different depth. The analysis of results shows that the area is not appropriate for borehole drilling.
\end{abstract}

Keywords: Geoelectric, Vertical Electrical Sounding, Groundwater Potential and Subsurface Layer

\section{Introduction}

Nigeria is considered to be abundantly blessed with water resources. However, there is temporal and spatial variation in water availability, the north with low precipitation of only about $500 \mathrm{~mm}$ in the northeastern region, and the south with low precipitation of over $4,000 \mathrm{~mm}$ in the southeast [5] According to the United Nations Development Programme, meaningful progress in water supply is fundamental environmental sustainable development. Food production as well as other socio-economic activities depends on availability of water [13]. Water has been a very important factor in settlement development in the country where it usually serves as human settlement boundaries [6]. Geophysical techniques together with geological, structural and hydrogeological mapping have shown a positive synergy. Understanding structures is the key to interpreting crustal movements that have shaped the present terrain. Structures also indicate potential sites for locating water, oil and gas reserved by characterizing both the underlying subsurface geometry of rock units and the amount of crustal deformation experienced by the rock body [10].

Nearly all the water in the ground comes from precipitation that has infiltrated into the earth. Observations have shown that a good deal of surplus rainfall runs off over the surface of the ground while the other part of it infiltrates underground and becomes the groundwater responsible for the springs, lakes and wells [9].

Groundwater can be used for agricultural, municipal and industrial works. Groundwater is also widely used as a source for drinking supply and irrigation [4] About 53\% of all population relies on groundwater as a source of drinking water. Most human requires about 2.5 litres of water everyday which justifies that the average amount of water used each day domestically by every person is around 190 litres [6].

Vertical Electrical Sounding (VES) is a geoelectrical method used to measure vertical alterations of electrical resistivity. The method has been recognised to be more suitable for a hydrogeological survey of the sedimentary 
basin [8]. Vertical Electrical Sounding has proven very popular with groundwater prospecting and engineering investigations due to simplicity of the techniques [1].

\section{Geology of the Area}

The study area is the school's field, adjacent the school's clinic, Bosso campus of Federal University of Technology Minna, Niger State which is part of Bosso local government in the city of Minna, Niger State, Nigeria. Bosso and its environs is the centre and major metropolitan of Minna the capital city of Niger State and has a land mass area of about
884 hectares [12].

The area investigated is part of the north-central Basement Complex of Nigeria which is composed of three lithological units, migmatite-gneiss complex, low grade schist belts and the older granite. Geological mapping revealed that the study area is underlain by granites, schist and gneiss with granites occupying greater portion of the area [7]. The structural mapping carried out in the area shows two principal joint directions along NE-SW and NW-SE. The river Chanchaga at the southern part of the study area which flows eastwards is structurally controlled.

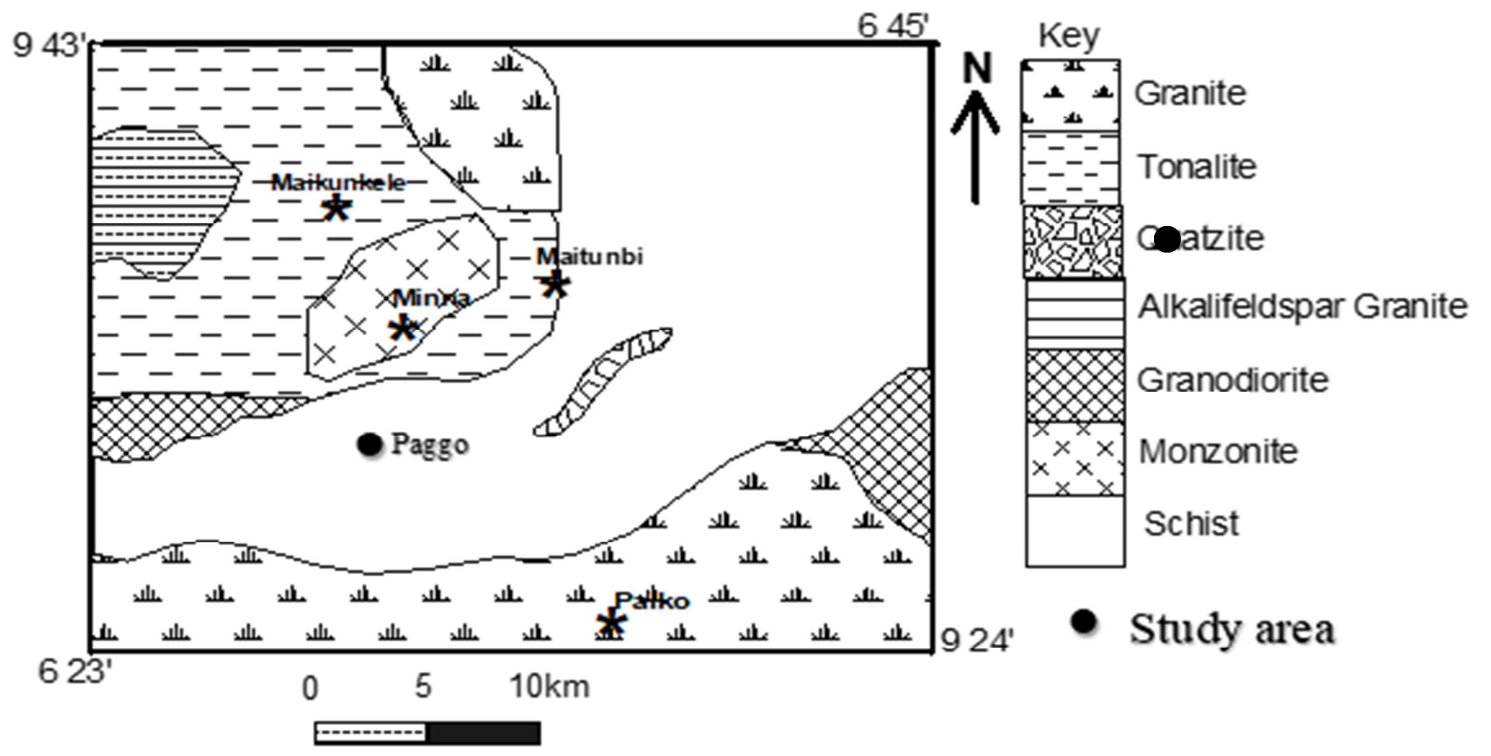

Figure 1. Geological Map of Minna [5].

\section{Materials and Methods}

The data was acquired with the Geotron G41Terrameter, Global Positioning System (GPS) for taking accurate coordinate of the VES point and elevations, Metal Electrodes, Measuring Tape, Labelled Tag (used in locating station position), Hammer (used in driving the electrodes into the ground). The Schlumberger array was adopted. The electrode spread of $\mathrm{AB} / 2$ was varied from 1 to a maximum of $100 \mathrm{~m}$. Sounding data were presented as sounding curves, by plotting apparent resistivity against $A B / 2$. The electrical resistances obtained were multiplied by the corresponding geometric factor $(\mathrm{k})$ for each electrode separation to obtain the apparent resistivity. The IPI2win software was then used to obtain the n-layer model curve for the Schlumberger sounding curves. This software automatically interprets the Schlumberger sounding curves. The plotted curves reveal the number of layers, thickness, depth and the average resistivity for each VES points automatically.

Resistivity measurements are to ascertain the level of water saturation and conductivity variation. This is because water has low resistance, and this makes the passage of electric current suitable. Water is being released and resistivity is increased by the increasing compaction of soil or rock units [14] expressed that the measurements of water are connected with the variability of depths with respect to the current and potential electrodes separation used in the survey, and can be illustrated in terms of lithological and geohydrological model of the subsurface [11].

Ground resistivity is measured by passing an electric current through the ground using two current electrodes and measuring the resultant potential using two or more potential electrodes. The depth of investigation is often given as a function of the electrode spacing. That is to say that the greater the spacing between the outer current electrodes, the deeper the electrical currents will flow in the Earth, thus the greater the depth of exploration. Therefore, the depth of investigation is normally $20 \%$ to $40 \%$ of the current electrode spacing depending on the structure of the Earth resistivity. Ohms law is generally used to calculate the resistance which is then multiplied by a geometric factor (usually denoted as $\mathrm{K})$ to calculate resistivity [14] as shown in equations (1) and (3).

Assuming an electrically conductive body lends itself to the description of a one-dimensional body (like a wire), the relationship between the current and potential distribution could be described by Ohm's law as:

$$
\mathrm{V}=\mathrm{IR}
$$


where $\mathrm{V}=$ the potential difference (in volts), $\mathrm{I}=$ current (in Amperes) and $\mathrm{R}=$ resistance (in ohms)

The resistance is therefore given by:

$$
R=\frac{V}{I}=\rho\left(\frac{L}{A}\right)
$$

For an area, A $\left(2 \pi r^{2}\right)$, equation (2) could be rewritten in terms of voltage, $\mathrm{V}$ as;

$$
V=\frac{\rho I}{2 \pi r}
$$

Considering an electrode pair with current I at the first electrode, and $-\mathrm{I}$ at the second electrode the potential at any point is given by the algebraic sum of the individual contributions. Hence,

$$
V=V_{c 1}+V_{c 2}=\rho I\left(\frac{1}{2 \pi r_{c 1}}-\frac{1}{2 \pi r_{c 2}}\right)=\frac{\rho I}{2 \pi}\left(\frac{1}{r_{c 1}}-\frac{1}{r_{c 2}}\right)
$$

where $r_{c 1}$ and $r_{c 2}=$ distances from the point between electrodes $\mathrm{C} 1$ and $\mathrm{C} 2$ respectively [16].

For the potential electrodes, $\mathrm{P} 1$ and $\mathrm{P} 2$ the potential is given as:

$$
V=V_{P 1}-V_{P 2}=\frac{\rho l}{2 \pi}\left(\frac{1}{C 1 P 1}-\frac{1}{C 2 P 1}+\frac{1}{C 2 P 2}-\frac{1}{C 1 P 2}\right)
$$

where $V_{P 1}$ and $V_{P 2}=$ potentials at $\mathrm{P}_{1}$ and $\mathrm{P}_{2}$

$\mathrm{C} 1 \mathrm{P} 1=$ distance between $\mathrm{C}_{1}$ and $\mathrm{P}_{1}$

$\mathrm{C} 1 \mathrm{P} 2=$ distance between $\mathrm{C}_{1}$ and $\mathrm{P}_{2}$

When we represent

$$
\frac{1}{2 \pi}\left(\frac{1}{A M}-\frac{1}{B M}+\frac{1}{B N}-\frac{1}{A N}\right)=\frac{1}{K}
$$

Equation (5) becomes

$$
V=\frac{\rho I}{K}
$$

From which resistivity is calculated i.e.:

$$
\rho=\frac{K V}{I}=R_{a p p} K
$$

where $\rho=$ resistivity (in ohm $\mathrm{m}$ ), $\mathrm{R}_{\mathrm{app}}=$ apparent resistance (in ohm) and $\mathrm{K}=$ geometric factor (in $\mathrm{m}$ ).

The geometric factor, $\mathrm{K}$ varies for different electrode configurations. According to [15], the geometric factor, $\mathrm{K}$ for the Wenner array is $2 \pi \mathrm{a}$. That of the Schlumberger array is given as;

$$
\frac{\pi}{a}\left[\left(\frac{s}{a}\right)^{2}-\left(\frac{a}{2}\right)^{2}\right]
$$

and the dipole-dipole array is given as

$$
\pi n(n+1)(n+2) a
$$

where $\mathrm{a}=$ electrode spacing

$\mathrm{s}=$ distance

$\mathrm{n}=$ dipole length factor.

\section{Results and Discussions}

\subsection{Criteria for Selecting Drilling Points}

Geoelectric methods for groundwater prospecting depend on the correlation of subsurface electrical properties. Resistivity profiling was conducted and selected points within low resistive zones were selected for vertical electrical

\begin{tabular}{|c|c|c|c|c|c|c|}
\hline Profile Name & VES station & LITHOLOGY & Layers & Res. $(\Omega m)$ & Thickness (m) & Depth (m) \\
\hline \multirow{17}{*}{ A } & \multirow{3}{*}{ A1 } & Top soil & 1 & 5.03 & 2.05 & 2.05 \\
\hline & & Fractured basement & 2 & 51.8 & 48.2 & 50.3 \\
\hline & & Fresh basement & 3 & 5.03 & $\infty$ & $\infty$ \\
\hline & \multirow{3}{*}{$\mathrm{A} 2$} & Top soil & 1 & 1.91 & 1.99 & 1.99 \\
\hline & & Clay / Clayey sand & 2 & 50.3 & 18.7 & 20.7 \\
\hline & & Fresh Basement & 3 & 2.07 & $\infty$ & $\infty$ \\
\hline & \multirow[t]{2}{*}{ A3 } & Clay/Clayey sand & 2 & 50.3 & 17.9 & 19.9 \\
\hline & & Fresh Basement & 3 & 1.99 & $\infty$ & $\infty$ \\
\hline & \multirow{3}{*}{ A4 } & Top soil & 1 & 1.92 & 2.12 & 2.12 \\
\hline & & Fractured Basement & 2 & 52.2 & 17.1 & 19.2 \\
\hline & & Fresh Basement & 3 & 2.02 & $\infty$ & $\infty$ \\
\hline & \multirow{3}{*}{ A5 } & Top Soil & 1 & 10.03 & 2.11 & 2.11 \\
\hline & & Clayey sand & 2 & 100 & 46.7 & 48.8 \\
\hline & & Fresh basement & 3 & 10.03 & $\infty$ & $\infty$ \\
\hline & \multirow{3}{*}{ A6 } & Clay & 1 & 193 & 2.05 & 2.05 \\
\hline & & Fractured Basement & 2 & 3115 & 46.7 & 48.8 \\
\hline & & Fresh Basement & 3 & 103 & $\infty$ & $\infty$ \\
\hline
\end{tabular}
sounding. It is important to note that low resistive zones may not all be potential groundwater areas. Depths with high resistivities may have hard consolidated material like granites, boulders or a dike-like structure, whereas low resistivities could be an indication of zones of fractured/weathered rocks or clays [2].

\subsection{Data Interpretation}

Table 1. Data Interpretation for Profile A. 
Table 2. Data Interpretation for Profile B.

\begin{tabular}{|c|c|c|c|c|c|c|}
\hline Profile Name & VES station & LITHOLOGY & Layers & Res. $(\Omega m)$ & Thickness (m) & Depth (m) \\
\hline \multirow{18}{*}{ (1) } & \multirow{3}{*}{ B1 } & Top soil & 1 & 2.74 & 1.99 & 1.99 \\
\hline & & Fractured basement & 2 & 161 & 18.5 & 20.5 \\
\hline & & Fresh basement & 3 & 1.99 & $\infty$ & $\infty$ \\
\hline & \multirow{3}{*}{ B2 } & Top soil & 1 & 0.671 & 2.05 & 2.05 \\
\hline & & Clay / Clayey sand & 2 & 20.5 & 18.4 & 20.5 \\
\hline & & Fresh Basement & 3 & 0.658 & $\infty$ & $\infty$ \\
\hline & \multirow{3}{*}{ B3 } & Top Soil & 1 & 58.3 & 2.02 & 2.02 \\
\hline & & Clay/Clayey sand & 2 & 367 & 45.7 & 47.7 \\
\hline & & Fresh Basement & 3 & 63.1 & $\infty$ & $\infty$ \\
\hline & \multirow{3}{*}{ B4 } & Top soil & 1 & 0.412 & 1.91 & 1.91 \\
\hline & & Fractured Basement & 2 & 19.9 & 18.8 & 20.7 \\
\hline & & Fresh Basement & 3 & 0.524 & $\infty$ & $\infty$ \\
\hline & \multirow{3}{*}{ B5 } & Top Soil & 1 & 5.78 & 1.99 & 1.99 \\
\hline & & Clayey sand & 2 & 205 & 18.5 & 20.5 \\
\hline & & Fresh basement & 3 & 6.78 & $\infty$ & $\infty$ \\
\hline & \multirow{3}{*}{ B6 } & Clay & 1 & 36.4 & 1.98 & 1.98 \\
\hline & & Fractured Basement & 2 & 626 & 47.6 & 49.6 \\
\hline & & Fresh Basement & 3 & 36.7 & $\infty$ & $\infty$ \\
\hline
\end{tabular}

Table 3. Data Interpretation for Profile C.

\begin{tabular}{|c|c|c|c|c|c|c|}
\hline Profile Name & VES station & LITHOLOGY & Layers & Res. $(\Omega m)$ & Thickness (m) & Depth (m) \\
\hline \multirow{18}{*}{ (2) } & \multirow{3}{*}{$\mathrm{C} 1$} & Top soil & 1 & 32.3 & 1.99 & 1.99 \\
\hline & & Fractured basement & 2 & 1989 & 17.9 & 19.9 \\
\hline & & Fresh basement & 3 & 35.1 & $\infty$ & $\infty$ \\
\hline & \multirow{3}{*}{$\mathrm{C} 2$} & Top soil & 1 & 74 & 2.05 & 2.05 \\
\hline & & Clay / Clayey sand & 2 & 1432 & 17.3 & 19.3 \\
\hline & & Fresh Basement & 3 & 81.1 & $\infty$ & $\infty$ \\
\hline & \multirow{3}{*}{$\mathrm{C} 3$} & Top Soil & 1 & 1.3 & 2.05 & 2.05 \\
\hline & & Clay/Clayey sand & 2 & 20.5 & 48.2 & 50.3 \\
\hline & & Fresh Basement & 3 & 1.39 & $\infty$ & $\infty$ \\
\hline & \multirow{3}{*}{$\mathrm{C} 4$} & Top soil & 1 & 6.74 & 2.07 & 2.07 \\
\hline & & Fractured Basement & 2 & 191 & 46.3 & 48.3 \\
\hline & & Fresh Basement & 3 & 6.68 & $\infty$ & $\infty$ \\
\hline & \multirow{3}{*}{$\mathrm{C} 5$} & Top Soil & 1 & 68.24 & 2.015 & 2.015 \\
\hline & & Clayey sand & 2 & 444.1 & 48.61 & 50.62 \\
\hline & & Fresh basement & 3 & 67 & $\infty$ & $\infty$ \\
\hline & \multirow{3}{*}{ C6 } & Clay & 1 & 0.711 & 2.02 & 2.02 \\
\hline & & Fractured Basement & 2 & 21.2 & 19.2 & 21.2 \\
\hline & & Fresh Basement & 3 & 0.741 & $\infty$ & $\infty$ \\
\hline
\end{tabular}

Table 4. Data Interpretation for Profile D.

\begin{tabular}{|c|c|c|c|c|c|c|}
\hline Profile Name & VES station & LITHOLOGY & Layers & Res. $(\Omega m)$ & Thickness (m) & Depth (m) \\
\hline \multirow{18}{*}{$\mathrm{D}$} & \multirow{3}{*}{ D1 } & Top soil & 1 & 0.0427 & 2.02 & 2.02 \\
\hline & & Fractured basement & 2 & 0.496 & 47.6 & 49.6 \\
\hline & & Fresh basement & 3 & 0.0449 & $\infty$ & $\infty$ \\
\hline & \multirow{3}{*}{ D2 } & Top soil & 1 & 1.49 & 2.12 & 2.12 \\
\hline & & Clay / Clayey sand & 2 & 49.6 & 18 & 20.2 \\
\hline & & Fresh Basement & 3 & 1.57 & $\infty$ & $\infty$ \\
\hline & \multirow{3}{*}{ D3 } & Top Soil & 1 & 5.05 & 2.05 & 2.05 \\
\hline & & Clay/Clayey sand & 2 & 199 & 18.4 & 20.5 \\
\hline & & Fresh Basement & 3 & 4.88 & $\infty$ & $\infty$ \\
\hline & \multirow{3}{*}{ D4 } & Top soil & 1 & 2.57 & 1.99 & 1.99 \\
\hline & & Fractured Basement & 2 & 50.3 & 46.3 & 48.3 \\
\hline & & Fresh Basement & 3 & 2.53 & $\infty$ & $\infty$ \\
\hline & \multirow{3}{*}{ D5 } & Top Soil & 1 & 12.4 & 2.05 & 2.05 \\
\hline & & Clayey sand & 2 & 205 & 48.2 & 50.3 \\
\hline & & Fresh basement & 3 & 12 & $\infty$ & $\infty$ \\
\hline & \multirow{3}{*}{ D6 } & Clay & 1 & 2.23 & 1.91 & 1.91 \\
\hline & & Fractured Basement & 2 & 48.3 & 48.4 & 50.3 \\
\hline & & Fresh Basement & 3 & 2.15 & $\infty$ & $\infty$ \\
\hline
\end{tabular}


Table 5. Data Interpretation for Profile E.

\begin{tabular}{|c|c|c|c|c|c|c|}
\hline Profile Name & VES station & LITHOLOGY & Layers & Res. $(\Omega m)$ & Thickness (m) & Depth (m) \\
\hline \multirow{18}{*}{ 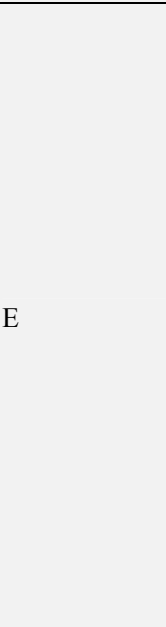 } & \multirow{3}{*}{ E1 } & Top soil & 1 & 0.946 & 1.99 & 1.99 \\
\hline & & Fractured basement & 2 & 50.3 & 17.1 & 19.1 \\
\hline & & Fresh basement & 3 & 0.96 & $\infty$ & $\infty$ \\
\hline & \multirow{3}{*}{ E2 } & Top soil & 1 & 0.0163 & 2.02 & 2.02 \\
\hline & & Clay / Clayey sand & 2 & 0.496 & 17.2 & 19.2 \\
\hline & & Fresh Basement & 3 & 0.0173 & $\infty$ & $\infty$ \\
\hline & \multirow{3}{*}{ E3 } & Top Soil & 1 & 3.37 & 2.02 & 2.02 \\
\hline & & Clay/Clayey sand & 2 & 47.2 & 47.6 & 49.6 \\
\hline & & Fresh Basement & 3 & 3.32 & $\infty$ & $\infty$ \\
\hline & \multirow{3}{*}{ E4 } & Top soil & 1 & 0.371 & 2.12 & 2.12 \\
\hline & & Fractured Basement & 2 & 21.2 & 18 & 20.2 \\
\hline & & Fresh Basement & 3 & 0.386 & $\infty$ & $\infty$ \\
\hline & \multirow{3}{*}{ E5 } & Top Soil & 1 & 10.1 & 1.99 & 1.99 \\
\hline & & Clayey sand & 2 & 96 & 48.3 & 50.3 \\
\hline & & Fresh basement & 3 & 10 & $\infty$ & $\infty$ \\
\hline & \multirow{3}{*}{ E6 } & Clay & 1 & 2.17 & 1.99 & 1.99 \\
\hline & & Fractured Basement & 2 & 50.3 & 48.3 & 50.3 \\
\hline & & Fresh Basement & 3 & 2.07 & $\infty$ & $\infty$ \\
\hline
\end{tabular}

Table 6. Data Interpretation for Profile F.

\begin{tabular}{|c|c|c|c|c|c|c|}
\hline Profile Name & VES station & LITHOLOGY & Layers & Res. $(\Omega m)$ & Thickness (m) & Depth (m) \\
\hline \multirow{18}{*}{$\mathrm{F}$} & \multirow{3}{*}{ F1 } & Top soil & 1 & 0.114 & 2.12 & 2.12 \\
\hline & & Fractured basement & 2 & 10 & 7.88 & 10 \\
\hline & & Fresh basement & 3 & 0.116 & $\infty$ & $\infty$ \\
\hline & \multirow{3}{*}{$\mathrm{F} 2$} & Top soil & 1 & 1.27 & 1.99 & 1.99 \\
\hline & & Clay / Clayey sand & 2 & 48.8 & 17.9 & 19.9 \\
\hline & & Fresh Basement & 3 & 1.2 & $\infty$ & $\infty$ \\
\hline & \multirow{3}{*}{$\mathrm{F} 3$} & Top Soil & 1 & 0.873 & 2.07 & 2.07 \\
\hline & & Clay/Clayey sand & 2 & 19.9 & 17.8 & 19.9 \\
\hline & & Fresh Basement & 3 & 0.886 & $\infty$ & $\infty$ \\
\hline & \multirow{3}{*}{$\mathrm{F} 4$} & Top soil & 1 & 1.83 & 1.99 & 1.99 \\
\hline & & Fractured Basement & 2 & 51.8 & 46.8 & 48.8 \\
\hline & & Fresh Basement & 3 & 1.99 & $\infty$ & $\infty$ \\
\hline & \multirow{3}{*}{ F5 } & Top Soil & 1 & 0.0451 & 2.07 & 2.07 \\
\hline & & Clayey sand & 2 & 10 & 7.34 & 9.41 \\
\hline & & Fresh basement & 3 & 0.0455 & $\infty$ & $\infty$ \\
\hline & \multirow{3}{*}{ F6 } & Clay & 1 & 0.0286 & 1.92 & 1.92 \\
\hline & & Fractured Basement & 2 & 362 & 3.3 & 5.22 \\
\hline & & Fresh Basement & 3 & 548 & $\infty$ & $\infty$ \\
\hline
\end{tabular}

\subsection{Iso-resistivity Map}

Through the computer aided software called Surfer, the iso resistivity map of an area is defined. The map helps to show the resistivity/conductivity variation with depth through the entire study area horizontal cross-section slicing. It also helps to delineate the lateral variation of the sub-surface geology of an area. These maps include the resistivity map of the topmost layer, $5 \mathrm{~m}, 10 \mathrm{~m}, 15 \mathrm{~m}$ e.t.c depth variation [3].

\subsubsection{Iso-resistivity Map at the Surface}

The iso-resistivity contour map at the surface was contoured at $50 \Omega \mathrm{m}$ interval as shown in figure 2 . The map shows a spatial variation of the resistivity of the topmost layer, which could be used to compare with the surface features like stream and exposed outcrops. The low range value region represents the loose earth material. The loose earth materials includes top soil, sandstone, clayey sand, humus e.t.c. The fractured or fairly weathered basement was found with resistivity value range between $330 \Omega \mathrm{m}$ and 860 $\Omega \mathrm{m}$. The fresh basement rock of very high resistivity value of
$1160 \Omega \mathrm{m}$ was found prominent.

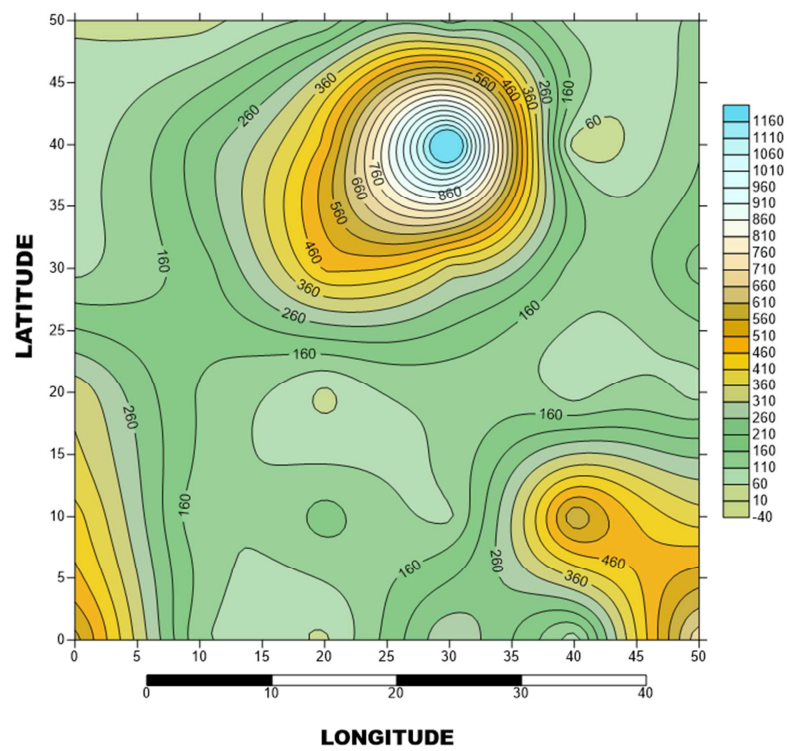

Figure 2. Iso-resistivity Map of the top soil. 


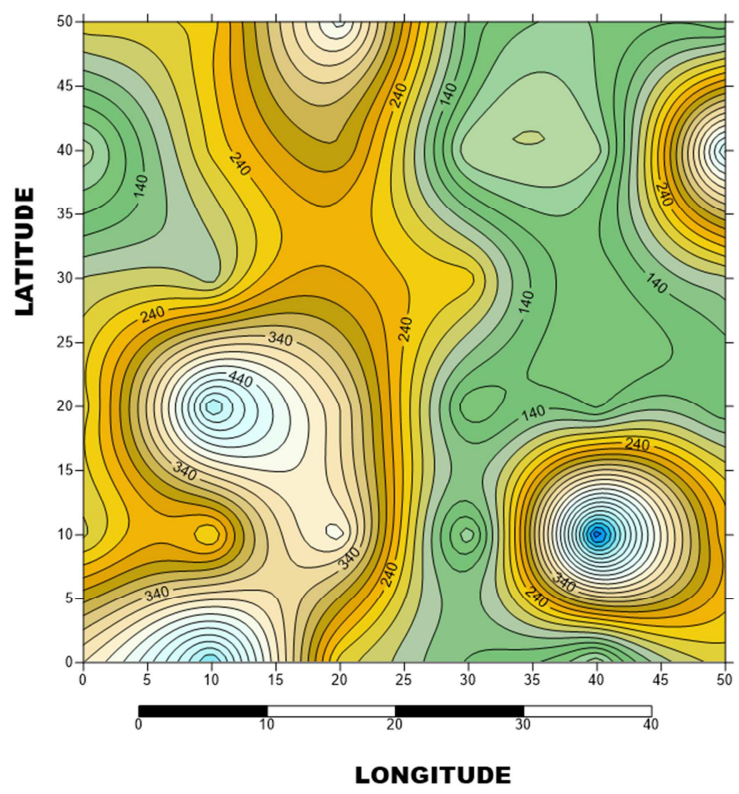

Figure 3. Iso-resistivity Map at the $5 \mathrm{~m}$ depth.

\subsubsection{Iso-resistivity Map at $5 \mathrm{~m}$}

The figure 3 shows a $20 \Omega \mathrm{m}$ interval contoured isoresistivity map at $5 \mathrm{~m}$ depth The low range value region represents the loose earth material. The loose earth materials signifies the top soil variation range with a resistivity value of $140 \Omega \mathrm{m}$. Also the highest resistivity value recorded within the fresh basement is $640 \Omega \mathrm{m}$.

\subsubsection{Iso-resistivity Map at $10 \mathrm{~m}$}

The figure 4 shows a $500 \Omega \mathrm{m}$ interval contoured isoresistivity map at $10 \mathrm{~m}$ depth. The depth range signifies no saturated (water) horizons within the subsurface. The fresh basement rock of very high resistivity value was recorded within the resistivity range of $5500 \Omega \mathrm{m}-8000 \Omega \mathrm{m}$.

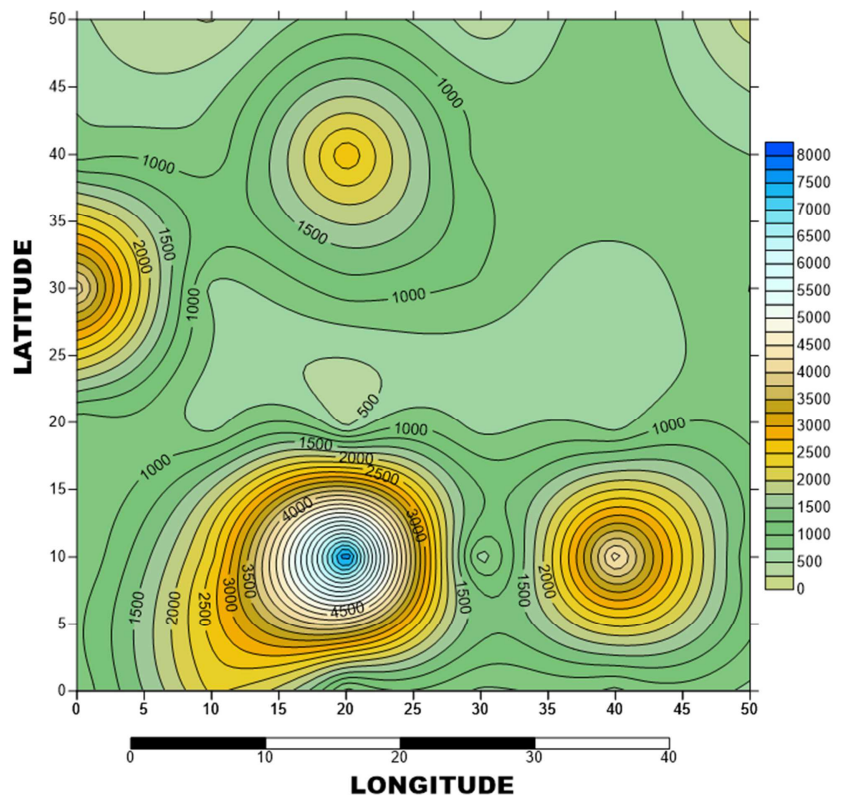

Figure 4. Iso resistivity at $10 \mathrm{~m}$ depth.

\section{Conclusion}

In this study, the groundwater potential was undertaken using vertical electrical soundings (VES). The curve type are simple three-layer types. The computer assisted sounding interpretation revealed subsurface sequence composing topsoil with limited hydrologic significance. The interpretation of the sounding results revealed that most of the profiles were underlain by an overburden thickness ranging from 12 to $16 \mathrm{~m}$. Moderately weathered material ranging from less than one meter to several meters in thickness separate the overburden from the underlying fractured bedrock and the hard bedrock. The bedrock may be associated with fractures in some of the communities and these resulted in relatively lower resistivities. Therefore the study area may be considered very poor for groundwater development.

\section{Recommendations}

The researcher observes that profiling at a constant depth of $60 \mathrm{~m}$ is a limitation on the study because prospective water-bearing zones could occur beyond this depth; hence further studies could be done to explore more boreholes in the district.

The electromagnetic method using Omega-M 2000 resistivity meter could also be used to locate resistivity anomaly zones that have the potential to store groundwater.

Resistivity method used for the project was efficient and reliable as the success rate was $64 \%$. Finally, further work to determine groundwater infiltration and consequent pollution from various minerals such as Iron, Magnesium and human activities should be done to ensure safety of consumers.

\section{References}

[1] Abiola O., P. A. Enikanselu and M. I. Oladapo (2009). Groundwater potential and aquifer protective capacity of overburden units in Ado-Ekiti, southwestern Nigeria International Journal of Physical Sciences, 4 (3), 120-132.

[2] Abdullahi N. K, Iheakanwa, A (2013). Groundwater Detection in Basement Complex of North- western Nigeria using 2D Electrical Resistivity and OffsetWenner Techniques, International Journal of Science and Technology, 2 (7).

[3] Alhassan, D. U, Mohammed I. N, Bature. M, Kimpa, M. I, and Mohammed, A. (2015): Electrical Resistivity Survey For ground Water at Eye Zheba Village, Off Bida - Minna Road. Journal of Applied Geology and Geophysics (IOSR-JAGG) India, (3), 49-53.

[4] Alile, O. M., Ujuanbi, O. and Evbuomwan, I. A., 2011. Geoelectric investigation of groundwater in Obaretin Iyanomon locality, Edo state, Nigeria. Journal of Geology and Mining Research, 3 (1), pp. 13-20.

[5] Alabi, A. A., 2011. Geology and Environmental Impact Assessment and Benefit of Granitic Rocks of Minna area, Northwestern Nigeria. Ethiopian Journal of Environmental Studies and Management, 4: 39-45. 
[6] Amadi, A. N., Olasehinde, P. I., Okosun, E. A. and Yisa, J., 2010. Assessment of the water quality index of Otamiri and Oramiriukwa Rivers. Physics International, 1 (2), pp. 116123.

[7] Anomohanran, O., 2015. Hydrogeophysical investigation of aquifer properties and lithological strata in Abraka, Nigeria. Journal of African Earth Sciences, 102, pp. 247-253.

[8] Iserhien-Emekeme, R. E., Atakpo, E. A., Emekeme, O. L. and Anomohanran, O., 2004. Geoelectric survey for groundwater in Agbede Etsako West LGA, Edo State. Adv. Nat. Applied Sci. Res, 2, pp. 65-72.

[9] Oseji, J. O., Asokhia, M. B. and Okolie, E. C., 2006. Determination of groundwater potential in obiaruku and environs using surface geoelectric sounding. Environmentalist, 26 (4), pp. 301-308.

[10] Muchiri L. Ambusso W., Githiri J. \& Cherop H.. (2016). Geophysical Investigation and Characterization of Groundwater Aquifers In Kangonde Area, Machakos County In Kenya Using Electrical Resistivity Method. IOSR Journal of Applied Geology and Geophysics, 4 (2), 23-35.

[11] Muturi N. Esther K. Maurice O. \& Githiri J. G. (2014),
Application of integrated geophysical techniques for groundwater potential evaluation in hard rock basement: mutito fault zone, Kenya, International Journal of Current. Trend, 2 (1), 18-28.

[12] Osinowo, O. O. Akanji, A. O. \& Akinmosin A. (2011). Integrated geophysical and Geotechnical investigation of the failed portion of a road in basement complex Terrain, Southwest Nigeria. Materials and Geoenvironment, 58 (2), 143-162.

[13] Ozegin, K. O. Oseghale A. Okolie E. C. \& Ujuanbi O. (2011). Integration of very low frequency electromagnetic (vlf-em) and electrical resistivity methods in mapping subsurface geologic structures favourable to road failures. International Journal of Water Resources and Environmental Engineering. $3(6), 126-131$.

[14] Plummer, C. C., McGeary, D. and Carlson, D. H., 1991. Physical geology (No. QE28. 2 P58 2005). Wm. C. Brown.

[15] Robinson, M. and Ward, R., 1990. Principles of hydrology. McGraw-Hill.

[16] Telford, W. M. Geldart, L. P. Sherrif, R. E. \& Keys D. A. (1976). Applied Geophysics. Cambridge University press, London. 